\title{
THERIOGENOLOGY
}

\section{PROLONGED SPRING OESTRUS IN MARES: THE USE OF PROGESTOGENS WITH SPECIFIC REFERENCE TO PROLIGESTONE}

\author{
W. van der Holst, ${ }^{1}$ P.H. van Laar ${ }^{2}$ and E.P. Oldenkamp ${ }^{2}$ \\ ${ }^{1}$ State University, Yalelaan 7 , Utrecht \\ 2 Gist-brocades N.V., Postbus 1, Delft \\ Received for publication: December 21, 1984 \\ Accepted: October 15, 1985
}

\begin{abstract}
The problems of prolonged spring oestrus in mares, which is often associated with multifollicular ovaries (MFO), are described in the context of the need to produce foals early in the year. The results obtained, in terms of pregnancy and time of ovulation, after the intramuscular administration of a single standard $15-\mathrm{ml}$ (1500 $\mathrm{mg}$ ) dose of proligestone are described and compared with data available for allyl trenbolone, ${ }^{b}$ which is given orally, and with accepted data for non-medicated mares. It is concluded that proligestone may be useful in treating MFO and that its use may even aid conception. This latter observation is worthy of further investigation.
\end{abstract}

Key words: prolonged spring oestrus, mares, proligestone

\section{INTRODUCTION}

Mares are seasonally polyoestrous. In the Northern Hemisphere they are in anoestrus during the winter months. Ovarian activity starts from February to April and regular cycles occur from May to October. The average duration of the cycle is 21 days with oestrus lasting for about 5 days. Mating usually takes place in the spring and early summer (1). Tests using artificial lighting have indicated that lighting patterns (intensity, duration and timing) play a large part in initiating ovarian activity, which also may be influenced by ambient temperature changes and feeding regimens (2-5). In some mares, before regular cycles start, an ovarian dyscyclicity may be noted without ovulation. When this occurs, such mares often show persistent signs of heat (prolonged spring oestrus), associated with the presence of multifollicular ovaries (MFO; 6). A typical feature of this condition is the passage of clear, light-coloured urine in contrast to the turbid yellow urine of mares having an ovulatory oestrus.

a Delvosteron, (R) Gist-brocades Animal Health, De Bilt
b Regumate, (R) Hoechst, Amsterdam

Acknowledgements:

The authors are indebted to Prof. Dr. M. Vandeplassche and Dr. M. Corijn for their advice and laboratory work. The help of Mr. J.M. Evans, MRCVS, in screening the text is gratefully acknowledged. Excellent technical assistance was provided by Bert Vink, manager of the Van de Water pony farm. We thank the staff and co-workers of the Veterinary University in Utrecht for their cooperation. 


\section{THERIOGENOLOGY}

A general aim of many breeders is for mares to foal as early as possible in the year. Thus, attempts have been made to advance the onset of the first fertile oestrus. Tests with varying artificial lighting programmes are a case in point $(7,8)$. Daily injections of 100 to $125 \mathrm{mg}$ of progesterone in oil will stimulate ovulation in MFo mares but are not practical $(9,10)$. Allyl trenbolone, a synthetic steroid hormone administered orally, in oil or as granules for 10 to 15 days, will suppress the signs of heat usually within three days after dosing commences. About five days after treatment is stopped, mares show signs of oestrus again, and after another five days ovulation occurs (11). Theoretically, fertility at such a "rebound" heat is unlikely to be adversely affected as the progestogen is given for a relatively short time. It is, however, difficult to find any relevant confirmatory information in the literature about mares (12-15).

A brochure is available, however, which reviews trials with allyl trenbolone in the UK and Australia. In the UK, 71 mares with prolonged spring oestrus were treated; 50 were serviced within 28 days after medication started and 25 (35\%) of the tolal group proved to be pregnant. In Australia, figures of 91,61 and 38 (42\%) were recorded respectively. Webel (16) reported that of 25 mares with MFO which had been serviced at the first ovulation after medication with allyl trenbolone, 14 (56\%) became pregnant. The time when pregnancy was established is not mentioned and the course of pregnancy is not discussed, so it is not known if embryonic death was a problem, how many foals were eventually born or if those foals showed any abnormalities that could have been linked with medication.

It is generally accepted, in Holland, that normal mares which receive no trcatment have a conception rate of about $25 \%$ whon serviccd early in the breeding season, although this percentage tends to vary considerably from one stud farm to the other and between breeds. Thus it would seem that medication with allyl trenbolone may improve fertility.

Because prolonged oral administration creates practical difficulties and uptake and absorption cannot be guaranteed, the possibility of obtaining the desired effect by the use of an injectable steroid hormone was considered. Since the commercially available preparation of proligestone, which is used to postpone and suppress oestrus in dogs and cats, had been shown to be effective in treating nymphomania in mares, that product was considered to be suitable for investigation. The results obtained with the product, which contains $10 \%$ aqueous suspension of proligestone, administered by the intramuscular route to mares with prolonged spring oestrus associated with multifollicular ovaries, are rcported. 


\section{THERIOGENOLOGY}

\section{MATERIALS AND METHODS}

A total of 47 mares ( 14 ponies and 33 horses) of different, known breeds were involved. These animals had no previous history of endometritis and bacteriological examination of uterine swabs yielded no significant pathogenic organisms. The animals were kept in stables until the end of April and were not exposed to more than the usual amount of artificial light. They were fed mixed hay and water ad libitum supplemented with concentrates. From May 1 the animals were turned out and not stabled at all. The mares were medicated when they showed the signs of MFO described earlier together with signs of heat. With the exception of one animal which weighed $700 \mathrm{~kg}$, the weights of the animals varied between $350 \mathrm{~kg}$ and $500 \mathrm{~kg}$.

Fifteen $\mathrm{ml}(1500 \mathrm{mg})$ of the commercial presentation of proligestone were administered by deep intramuscular injection into the gluteal muscles of each animal.

The mares were teased every other day, and the cervix, uterus and ovaries were examined by rectal palpation to confirm that all the animals treated had a certain degree of follicular development but had no preovulatory or ovulatory follicles.

From December 17 to April 24, 1982, blood samples were taken one to three times a week from the jugular veins of the same, randomly selected group of ten mares to determine plasma progesterone levels. Sampling stopped once ovulation had been confirmed by rectal palpation. The blood was collected in heparinized Vacutainers. It was centrifuged at $1,000 \mathrm{~g}$ for ten minutes, after which the plasma was transferred to 5-m1 plastic tubes for storage at $-25{ }^{\circ} \mathrm{C}$. The samples were tested retrospectively for progesterone levels using the method described by Allen (2).

Once clinical examination indicated that a mare was ready for service, it was mated or inseminated during the first oestrus following the administration of proligestone and at subsequent oestrus periods until it became pregnant.

A rectal examination to establish pregnancy was carried out in all mares on days 21 to 24 after mating or insemination. A second rectal examination to confirm pregnancy took place about six weeks later.

Treatment with proligestone was considered successful if the mare ovulated on day 24 or earlier after medication. It should be remembered that the mean equine cycle lasts 21 days while signs of heat disappear on average within three days. 


\section{THERIOGENOLOGY}

RESULTS

The plasma levels of progesterone in all the samples taken regularly from the group of ten mares were lower than 1 nanogram $/ \mathrm{ml}$, indicating that spontaneous ovulation had not occurred in these animals during the period of observation. The signs of heat, as judged by behaviour observation and teasing, disappeared in all mares within one to four days (average: three days) after medication. The effect of medication in respect of the time of ovulation is shown in Table 1. In $68 \%$ of the cases the injection was judged successful. The effect of proligestone

Table 1. Time of ovulation after medication with proligestone

\begin{tabular}{|l|c|c|}
\hline Result & Number & Percentage \\
\hline Ovulation \$24 days & 32 & 68 \\
Ovulation >24 days & 14 & 30 \\
No ovulation & 1 & 2 \\
\hline Total & 47 & $100 \%$ \\
\hline
\end{tabular}

medication in relation to time of injection is presented in Table 2. The results suggest that efficacy may decrease as the breeding season progresses but this requires confirmation by trials involving a greater number of animals. The percentage of mares becoming pregnant after

Table 2. Time of ovulation analysed by month of medication

\begin{tabular}{|c|c|c|c|c|c|c|}
\hline Result & Jan & March & April & May & June/Aug & Total \\
\hline $\begin{array}{l}\text { Ovulation } \leqslant 24 \text { days } \\
\text { Ovulation }>24 \text { days } \\
\text { No ovulation }\end{array}$ & $\begin{array}{l}1 \\
- \\
-\end{array}$ & $\begin{array}{r}16 \\
7 \\
-\end{array}$ & $\begin{array}{l}6 \\
2 \\
-\end{array}$ & $\begin{array}{l}5 \\
3 \\
-\end{array}$ & $\begin{array}{l}4 \\
2 \\
1\end{array}$ & $\begin{array}{r}32 \\
14 \\
1\end{array}$ \\
\hline Total & 1 & $\frac{23}{24}$ & 8 & 8 & 7 & 47 \\
\hline
\end{tabular}


medication and subsequent services, as judged by rectal palpation about six weeks after the last service or insemination, is indicated in Table 3. Overall the pregnancy rate was $87 \%(39 / 45)$ and in the animals which ovulated on day 24 or earlier after medication, the pregnancy rate was $93 \%$, excluding the two animals in which the outcome was unknown. The

Table 3. Pregnancy rate in animals ovulating on day 24 or earlier or more than 24 days after medication

\begin{tabular}{|l|c|c|c|c|}
\hline Result & $\begin{array}{c}\text { Number of } \\
\text { mares }\end{array}$ & Pregnant & Not pregnant & Unknown \\
\hline Ovulation $\leqslant 24$ days & 32 & 28 & 2 & 2 \\
Ovulation >24 days & 14 & 11 & 3 & - \\
No ovulation & 1 & - & 1 & - \\
\hline Total & 47 & 39 & 6 & 2 \\
\hline
\end{tabular}

relationship between month of treatment and conception in the animals where medication was successful is shown in Table 4, which also indicates which post-treatment ovulation was followed by pregnancy. Where results were known, $77 \%$ of the animals conceived at the first ovulation after medication. This result was not significantly affected by the month of year when medication was given.

Table 4. Time of conception in mares ovulating on day 24 or earlier after medication analysed by the month of the year when they were injected with proligestone

\begin{tabular}{|c|c|c|c|c|c|c|}
\hline \multirow{2}{*}{$\begin{array}{l}\text { Time of } \\
\text { treatment }\end{array}$} & \multicolumn{3}{|c|}{ Pregnant after } & \multirow{2}{*}{$\begin{array}{l}\text { Not } \\
\text { pregnant }\end{array}$} & \multirow[t]{2}{*}{ Unknown } & \multirow[t]{2}{*}{ Total } \\
\hline & $\begin{array}{l}\text { lst } \\
\text { ovulation }\end{array}$ & $\begin{array}{l}\text { 2nd } \\
\text { ovulation }\end{array}$ & Later & & & \\
\hline $\begin{array}{l}\text { Jan } \\
\text { March } \\
\text { April } \\
\text { May } \\
\text { Jun/Aug }\end{array}$ & $\begin{array}{r}- \\
11 \\
5 \\
4 \\
3\end{array}$ & $\begin{array}{l}- \\
3 \\
- \\
- \\
1\end{array}$ & $\begin{array}{l}- \\
- \\
- \\
-\end{array}$ & $\begin{array}{l}1 \\
- \\
1 \\
- \\
-\end{array}$ & $\begin{array}{l}- \\
2 \\
- \\
- \\
-\end{array}$ & $\begin{array}{r}1 \\
16 \\
6 \\
5 \\
4\end{array}$ \\
\hline Total & 23 & 4 & 1 & 2 & 2 & 32 \\
\hline
\end{tabular}




\section{THERIOGENOLOGY}

Sixty-seven percent of the 39 pregnant mares conceived after the first ovulation, $18 \%$ after the second ovulation and $15 \%$ after a subsequent ovulation. A total of 24 mares was treated from January 1 to April 1; 17 ovulated within 24 days of treatment, and $11(65 \%)$ became pregnant after the first ovulation, which indicated that the breeding season can be successfully advanced by medication with proligestone. Pregnancy was confirmed by rectal palpation in 39 out of 42 mares which appeared to be pregnant before 24 days after service. This indicates that embryonic mortality may have occurred in three cases (7\%). This figure is lower than the $10 \%$ to $20 \%$ embryonic mortality rate which occurs normally (17, 18). There was a numerical trend $(0.05<P<0.10)$ for horses to respond better than ponies since more horses ovulated on day 24 or earlier after treatment. However, the result in ponies may have been somewhat unfavourably affected by the fact that the breeding season starts later in these animals $(19,20)$.

No side effects were seen at the injection site or in the general health condition of any of the animals.

No congenital abnormalities were found in 19 of the 39 foals born. The rest of the foals were not available for examination because they had been moved to other stud farms.

\section{DISCUSSION}

The results obtained in this study with a single parenteral injection of proligestone are helpful to make a comparison with the figures given in the paper by Webel (16) and in the allyl trenbolone brochure and accepted data for non-medicated mares $(12,15,20)$. The ovulation rate $(68 \%)$ within a fixed period of 24 days after medication agrees with the rate (67\% to $70 \%$ ) reported for allyl trenbolone, which was judged at 28 days after medication. In a parallel study involving nine untreated mares in which MFO was diagnosed during the first two weeks of February, ovulation did not occur until 80 days (range 76 to 108) after the condition was noted. When assessing the relevance of these figures it should be borne in mind that these animals were observed earlier in the year, when a longer interval to ovulation would be expected, but on the other hand they were kept outside, a factor that would tend to hasten ovulation.

Table 2 shows that $65 \%$ of the mares treated in the first few months and serviced (January to April 1) ovulated within that period and could thereby be serviced or inseminated much earlier. In countries of the Northern Hemisphere, such as Holland, mating usually takes place after April 1 although race horses are usually bred earlier. 


\section{THERIOGENOLOGY}

Of practical importance is, of course, how many mares thus treated become pregnant. These results are shown in Table 3 . Excluding two mares in which the outcome remained unknown, $87 \%$ of those medicated became pregnant, a figure which compares favourably with the national average of about $70 \%$ after normal service or insemination.

Pregnancy rates following induced ovulation in the two allyl trenbolone trials previously mentioned were $25 / 71$ (35\%) and $38 / 91$ (42\%), respectively. Tests by Webel in a group of 36 mares indicated pregnancy in $18(50 \%)$. In neither case were the moment and method of pregnancy diagnosis or the time of treatment reported. The comparable outcome with proligestone is $23 / 45(51 \%)$.

The pregnancy figures listed in Table 4 in relation to the time of medication are concerned with mares ovulating on day 24 or earlier. They show that of the 32 mares treated before May $1,15(47 \%)$ became pregnant at the first ovulation after medication. The latter percentage compares very favourably with the results obtained following normal service or insemination at the first ovulation in the breeding season in non-medicated animals (about 25\%).

A single parenteral treatment offers practical advantages compared to daily oral administration for two wccks. Apart from the extra work involved with oral doses, it is not certain that the correct amount will be given because of lack of accuracy in the dose measurement. Furthermore, the correct amount may not be taken by the animal or absorption from the intestinal tract may in some way be impaired.

The results of this study suggest that proligestone might have a useful role to play in improving fertility in mares. However, the fact that the number of horses, included in the study was small and that control animals, both nonmedicated and dosed with other progestogens, were not examined at the same time makes interpretation of the data difficult. Nevertheless the findings are interesting and will hopefully stimulate further investigation. For example, in this study a standard dose of $1500 \mathrm{mg}$ was given to all animals. It would be interesting to carry out dose-ranging studies to determine the optimum dose on a body weight basis and, at the same time, compare the efricacy of pruligeslune with other progestogens in respect of fertility, embryonic mortality and the interval to ovulation after medication. 


\section{THERIOGENOLOGY}

\section{REFERENCES}

1. Leeuwen, W. van. Acyclicity and discyclicity in mares. Tijdschr. Diergeneesk. 102: 86-105 (1977).

2. Allen, W.R. Artificial control of the mare's oestrus cycle. Vet. Rec. 100: 68-71 (1977).

3. Oxender, W.D., Noden, P.A. and Hofs, H.D. Estrus, ovulation and serum progesterone, estradiol and LH concentrations in mares after an increasing photoperiod during winter. Am. J. Vet. Res. 38: 203-208 (1977).

4. Palmer, E. Control of the oestrus cycle of the mare. J. Reprod. Fertil. 54: 495-505 (1978).

5. Henry, M., Coryn, M. and Vandeplassche, M. Multiple ovulation in the mare. Zbl. Vet. Med. A. 29: 170-184 (1982).

6. Holst, W. van der and 0ldenkamp, E.P. Die Anwendung von Proligeston bei Pferden mit multiplen, follikulären Ovarien. Proceedings D.V.G. München. Zuchthyg. 18: 130 Abstr. (1983).

7. Kooistra, L.H. and Ginther, O.J. Effect of photoperiod on reproductive activity and hair in mares. Am. J. Vet. Res. 36: 1413-1419 (1975).

8. Palmer, E. Reproductive management of mares without detection of oestrus. J. Reprod. Fertil. Suppl. 27: 263-270 (1979).

9. Dinger, J.E. and McCall, J.P. Plasma progestogen levels in pregnant mares following administration of exogenous progesterone. Theriogenology 15: 405-413 (1981).

10. Loy, R.G., Pemstein, R., O'Canna, D. and Douglas, R.H. Control of ovulation in cycling mares with ovarian steroids and prostaglandin. Theriogenology 15: 191-198 (1981).

11. Allen, W.R. and Urwin, V. Preliminary studies on the use of an oral progestogen to induce oestrus and ovulation in seasonally anoestrus thoroughred mares. Equine vet. J. 12: 141-145 (1980).

12. Evans, M.J. and Irvine, C.H.G. Serum concentrations of FSH, LH and progesterone during the oestrus cycle and early pregnancy in the mare. J. Reprod. Fertil. Supp1. 23: 193-200 (1975). 


\section{THERIOGENOLOGY}

13. Nitschelm, D. and Horst, C.J.G. van der. The influence of chlormadinone acetate treatment on the concentration of some steroids in the blood, on the ovarian activity and on the sexual behaviour of the mare. Tijdschr. Diergenecsk. 102: 805-816 (1977).

14. Squires, E.L., Stevens, W.B., McGlothlin, D.E. and Pickett, B.W. Effect of an oral progestin on the oestrus cycle fertility of mares. J. Anim. Sci. 49: 729-735 (1979).

15. Stabenfeldt, G.H., Edqvist, L.-E., Kindahl, H., Gustafsson, B. and Bane, A. Practical implications of recent physiologic findings for reproductive efficiency in cows, mares, sows and ewes. J. Am. Vet. Med. Assoc. 172: 667-675 (1978).

16. Webel, S.K. and Squires, F.L. Control of oestrus cycle in mares with altrenogest. J. Reprod. Fertil. Suppl. 32: 193-198 (1982).

17. Badi, A.M., Byrne, T.M.O. and Cunningham E.P. An analysis of reproductive performance in thoroughbred mares. Irish Vet. J. 35: $1-12$ (1981).

18. Murray, G. A cytogenetical study of prenatal loss in the mare. Theriogenology 15: 295-309 (1981).

19. Freedman, L.J., Garcia, M.C. and Ginther, O.J. Influence of ovaries and photoperiod on reproductive function in the mare. J. Reprod. Fertil. Suppl. 27: 79-86 (1979).

20. Wesson, J.A. and Ginther, O.J. Puberty in the female pony: reproductive behaviour, ovulation and plasma gonadotrophin concentrations. Biol. Reprod. 24: 977-986 (1981). 